\title{
Attitude to Humour and Jokes in Children with Mild Intellectual Disabilities
}

\author{
Pavel Zikl ${ }^{1, a}$, Markéta Levínská ${ }^{2, b}$, Kristýna Honzíčková ${ }^{3, c}$, Lucie Brabcová ${ }^{4, d}$, \\ Petra Bambulová ${ }^{5, e}$ and Vendula Kročilová ${ }^{6, f}$ \\ 1,2,3,4,5,6 Faculty of Education, University of Hradec Králové, Rokitanského 63, Hradec \\ Králové 3, 500 03, Czech Republic \\ apavel.zikl@uhk.cz, ${ }^{b}$ marketa.levinska@uhk.cz, 'kristyna.honzickova@uhk.cz \\ dlucie.brabcova@uhk.cz, ${ }^{\mathrm{e}}$ petra.bambulova@uhk.cz, ${ }^{f}$ vendula.krocilova@uhk.cz
}

Keywords: mild intellectual disability, sense of humour, anxiety, knowledge development, child development, cartoons

Abstract. This paper focuses on the comparison of sense of humour and attitudes to humour in a peer group of 10-11 year-olds. It surveys children with normal intellectual abilities and children with mild intellectual disability (mild ID). The SHQ-6 questionnaire and a set of cartoons were used as research tools. Although children with mild ID regard humourists as irritating and they feel uncomfortable in situations where someone jokes, they generally laugh more. Does it mean they understand jokes better, if they laugh more?

\section{Introduction}

Many research studies have been conducted addressing the topic of humour and there are a number of established classics in the field which deserve to be mentioned [1]. Research of the culture at Czech schools has a tradition in the Czech Republic and several research teams addressed this topic $[2,3]$. There also exist major studies studying the function of humour in school children [4]. We are interested in humour as a phenomenon allowing mutual interactions between children educated separately in the Czech educational system - some attending mainstream elementary school and others schools for pupils with mild mental disabilities. In a pilot research study that focuses on a comparison of sense of humour across a group of children with different intellectual abilities and studies their sense of humour in relation to the cultural setting in which they had been encultured, we present the results achieved by performing the SHQ-6 test [5] on a group of children with normal intellectual capacity and a group of children diagnosed with mild ID.

\section{Theory}

According to research studies, sense of humour and attitudes to humour are related to the level of cognitive development of the individual [6,7]. A qualitative change occurs at the age of 11-12 [8]. The acquisition of schemata together with development of intellectual operations enables understanding of more complex jokes $[8,9]$. According to the cognitivist concept, jokes are a result of disruption of the anticipated schema, and the punchline is a result of a situation of conceptual incongruity. [11]. The question is whether children with mild ID have the same understanding of jokes as their peers without mild ID. Understanding condensed situations such as situations presented in jokes requires certain cultural experience that is related to shared cultural values and norms that constitute a cultural identity [12]. We believe that similarly as intelligence tests [13] also humorous situations or jokes are conditioned by cultural experience. Another obvious piece of information is that humour is one of the coping strategies employed to manage anxiety [1]. Shared humour reinforces social bonds and sharing of humorous situations and laughter reinforces group identity [4]. On the other hand, hostile jokes may exclude those not belonging to the group or may be considered an act of sublimed aggression [4].

The complexity of humour and sense of humour as a phenomenon raises the question whether humour can play a bond-forming role in various peer groups and whether it can help overcome 
intellectual and social barriers. Another question that can be raised is what kind of barriers to understanding jokes are posed by reduced intellectual capacity and whether the function of the super-ego as the structure benefiting from a joke is the same in both groups. Super-ego consists of internalized cultural notions and norms acquired in early childhood and, at the same time, it is also the structure that provides the pleasure found by the ego in humour [15].

\section{Methodology}

The aim of our partial survey was to get an idea whether it is possible at all to talk about different attitudes to humour in the context of normal and slightly reduced intellectual capacity. To determine the attitude to humour, we used the SHQ_6 questionnaire, which measures the meta message sensitivity (M-items) and attitude to humorous situations, liking of humorous situation (L-items) [5]. To verify the ability to laugh, we compiled a test series of 23 images of which 21 were a joke and 2 represented a normal situation.

The images used in the test were compiled based on an analysis of cartoons from children's magazines (ABC, Mateřídouška) and websites intended for children (www.alik.cz, www.detsky.net, www.detskestranky.cz, www.detsky-web.cz and www.psina.cz). 240 jokes were collected from the period of 1990-2016, two thirds of the jokes were from the period of 2012-2015. The jokes used in the test were jokes with no or very little accompanying text, and the punchline was achieved by a single cartoon picture. Cartoon strips were not included in the analysed set. Also jokes with racist, sexual or violent content were excluded. The selected jokes were redrawn in order to achieve similar graphic appearance and to eliminate the impact of the cartoonist's style on the evaluation of jokes and to allow the respondents to focus exclusively on the schema presented by the joke. The set included simple jokes with a single time plane: the structure of the joke consisted in a paradox or use of the schema in a different context. Complicated jokes were jokes involving two time planes, jokes presenting a situation that tuned into a paradox as a result of an action or reaction, or where the presented schema was put in a different context. Another important aspect was the selection of the main character- in terms of relationship to the punchline it is irrelevant whether this character represents a smart person (fox) or stupid person (moron) [8, 10]. Another important factor for differentiating jokes is the generic aspect; whether the main character is a human being or a symbolic figure and to what extent does the child have an opportunity to identify with the hero. For each of the jokes, children were asked to indicate the intensity of comicality (using a five-point rating scale consisting of "smileys") and the interviewer also measured the time required to understand the joke and established the respondents' overall response according to the intensity of laughter.

The survey was conducted in April and May 2016, and the researched group consisted of children at the upper end of the lower primary school grades (grades 4 and 5) aged 10-12 years. The average age of intact children was 10.7 years and the average age of children with mild ID was 11.7 years (they often start attending school with a one-year delay and they also more frequently repeat the same grade). 48 children, of which 24 boys and 24 girls, were from common primary schools, and 48 children belonged to a group attending school for pupils with mild ID, of which 24 were boys and 24 girls. Children from common schools were selected by paired selection (gender, grade).

\section{Pilot Survey Results}

The results obtained from the HSQ 6 questionnaire are shown in Table 1. Statistically significant difference between the two studied groups of children was identified in replies to questions measuring attitude to humorous situations, liking of humorous situation (L-items). Children with mild ID consider humourists as more irresponsible and less reliable (HSQ 2), and they show a stronger tendency to be put out of ease by humourists (HSQ 5). The difference between the two 
groups in responses to questions focusing on meta message sensitivity (M-items) was markedly pronounced and the difference was far beyond the limit of statistical significance.

Table 1 Comparison of the HSQ 6 questionnaire in children with normal intellectual capacity and in children with mild ID.

\begin{tabular}{|c|c|c|c|c|}
\hline & $\begin{array}{l}\text { Children with } \\
\text { normal } \\
\text { intellectual } \\
\text { capacity } \\
\text { (average } \\
\text { rating) }\end{array}$ & $\begin{array}{l}\text { Children with } \\
\text { mild ID } \\
\text { (average } \\
\text { rating) }\end{array}$ & $\begin{array}{c}\text { Rating of } \\
\text { statements by } \\
\text { children with } \\
\text { mild ID } \\
\text { higher/lower } \\
\text { by: }\end{array}$ & $\begin{array}{l}\text { Statistically } \\
\text { significant } \\
\text { difference } \\
\mathrm{T} \text { test } \\
(\mathrm{Yes} / \mathrm{No})\end{array}$ \\
\hline $\begin{array}{l}\text { HSQ_01: Do you easily recognize a mark of } \\
\text { humorous intent? } \\
\text { (1: Very easy - } 4 \text { : Very sluggishly) * }\end{array}$ & 2.09 & 2.39 & $14.4 \%$ & $\begin{array}{c}\text { NO } \\
(0.102)\end{array}$ \\
\hline $\begin{array}{l}\text { HSQ_02: Persons who are always out to be } \\
\text { funny are really irresponsible types not to be } \\
\text { relied upon. } \\
\text { (1: Not at all -: Yes, indeed) }\end{array}$ & 1.89 & 2.65 & $40.2 \%$ & $\begin{array}{c}\text { YES } \\
(0.000)\end{array}$ \\
\hline $\begin{array}{l}\text { HSQ 03: Do you consider yourself to be a } \\
\text { mirthful person? } \\
(1: \text { Yes indeed - } 4 \text { : Not at all) }\end{array}$ & 2.09 & 2.33 & $11.5 \%$ & $\begin{array}{c}\mathrm{NO} \\
(0.160)\end{array}$ \\
\hline $\begin{array}{l}\text { HSQ_04: Would you easily find something } \\
\text { humorous in most situations if you really } \\
\text { tried? } \\
\text { (1: Very easy - } 4 \text { : Very difficult) }\end{array}$ & 2.28 & 2.52 & $10.5 \%$ & $\begin{array}{c}\text { NO } \\
(0.196)\end{array}$ \\
\hline $\begin{array}{l}\text { HSQ_05: Humourists irritate me because } \\
\text { they so blatantly revel in getting others to } \\
\text { laugh. } \\
\text { (1: Not at all }-4 \text { : Yes indeed) }\end{array}$ & 1.77 & 2.37 & $33.9 \%$ & $\begin{array}{c}\text { YES } \\
(0.001)\end{array}$ \\
\hline $\begin{array}{l}\text { HSQ_06: Do you easily smile and laugh? } \\
\text { (1: Very easy - } 4 \text { : Very difficult) }\end{array}$ & 1.74 & 1.96 & $12.6 \%$ & $\begin{array}{c}\mathrm{NO} \\
(0.237)\end{array}$ \\
\hline \multicolumn{5}{|c|}{$\begin{array}{l}\text { * Every question in the test is rated on a 4-point rating scale. Limit values are shown for illustrative purposes } \\
\text { here. }\end{array}$} \\
\hline
\end{tabular}

In the second part of the research we focused on comparing the perceived comicality of cartoons. Statistical evaluation showed that children with mild ID evaluated images generally as slightly more humorous, but below the limit of statistical significance. . With a statistically significant difference, the group with mild ID evaluated control pictures, which were not actually funny, as more humorous. While children with normal intellectual capacity evaluated the control images as depicting a "normal situation", the children with mild ID assessed these with on the average one point higher scores on the 5-point scale evaluating them as "slightly funny" (a smiling smiley). A result confirming our expectations were different ratings of cartoons requiring more complex visual analysis or cartoons with intellectually more demanding text.

\section{Summary}

An interesting paradox can be observed in the results of the survey. Children with mild ID expressed agreement with the following statements: "Persons who are always out to be funny are really irresponsible types not to be relied upon." and "Humourists irritate me because they so blatantly revel in getting others to laugh.". At the same time, during the test they laughed more 
often and they often evaluated jokes as more funny. Referring to the psychoanalytic theory [15], we believe that this paradox can be explained by higher levels of anxiety in children with mild ID. They feel uncertain in the presence of the joking others, whether it is because they are not sure whether the joke or the funny act might be directed against them, or because they do not understand the joke or humour. On the other hand, they often laugh, even if the cartoon is apparently neutral. This finding can be interpreted as readiness to express emotions, as lower control over emotions or as a defence mechanism that helps them maintain internal integrity.

\section{Acknowledgements}

The research was conducted with the support of the Faculty of Education, University of Hradec Kralove as part of a specific research.

\section{References}

[1] R. A. Martin: The Psychology of Humour. An Integrative Approach (Elsevier Academic Press, United States of America 2007).

[2] Pražská skupina školní etnografie (Prague Group of School Ethnography). Psychický vývoj ditěte od 1.-5. trídy (Psychical Development of a Child between the First and the Fifth Grade) (Karolinum, Czech Republic 2005).

[3] R. Švaříček, K. Šed'ová and Z. Šalamounová: Komunikace ve školní třídě (Communication in the Classroom) (Portál, Czech Republic 2012)

[4] K. Šed'ová. Humor ve školní třídě (Humor in the Classroom) (Masarykova Univerzita, Czech Republic 2013)

[5] S. Svebak: The sense of Humor Questionnaire: Conceptualization and rewiev of 40 years of findings in empirical research. Europe's Journal of Psychology, 6 (3), (2010) pp. 288-310

[6] M. Kučera, M. Klusák: Dětské hry - Games (Karolinum, Czech Republic 2010)

[7] J. M. Havigerová, E. Holečková: in: ICERI2015 Proceedings, edited by L.G. Chova, A.L. Martínez and I.C. Torezz, IATED Academy Spain (2015), p. 2181-2189.

[8] M. Pejchalová: Practical and Elementary School Diploma thesis. (Pedagogická fakulta Univerzity Karlovy v Praze, Czech Republic, 2014) p.75-77

[9] J. Piaget, B. Inhelder: The Psychology of the Child. (Basic Books, USA 1962)

[10] L. Kmet'ko: Vtipy v Subkultúre dětí mladšieho školského věku: pokus o lingvistickú analýzu (Jokes in the Sub-Culture of Young School Children: an Attempt for Linguistic Analysis). Diploma thesis. (Pedagogická fakulta Univerzity Komenského v Bratislavě, Slovenská republika, 2000)

[11] P. E. McGhee: Humor its origin and developement (W.H Freeman \& Co Ltd, 1979)

[12] D. Bittnerová, in: Kdo jsem a kam patřím? (Who I am and Where I Belong), edited by D. Bittnerová a M. Moravcová. Sofis, Czech Republic 2015

[13] T. Nikolay in: Schola excludus, edited by Z.Svoboda and P.Morvayová University of JEP, Czech Republic (2010), p. 90-117

[14] S. Freud: Humor Int J. Psycho Anal 9(1) 1928, p.1-6

[15] S. Freud: Přednášky k úvodu do psychoanalýzy: Nová rada přednášek k úvodu do psychoanalyzy (Introductory Lectures on Psychoanalysis). (Avicenum, Praha 1991) 